\title{
Flashcard As A Learning Media For Early Childhood
}

\author{
I Ketut Sudarsana ${ }^{1}$, Putu Andre Suhardiana ${ }^{2}$, Putu Santi Oktarina ${ }^{3}$, Ni Kadek Sari Dantha ${ }^{4}$ \\ \{liketutsudarsana@uhnsugriwa.ac.id\} \\ ${ }^{1234}$ Universitas Hindu Negeri I Gusti Bagus Sugriwa Denpasar, Bali, Indonesia
}

\begin{abstract}
Educational technology that is part of education with all aspects of human learning problem solving through complicated and interrelated processes also participate in efforts to increase the quality of education through ways and methods tailored to the needs, growth and development of learners. Early childhood education is an effort to optimize the growth of children through learning that is more focused on children through play activities so that in these activities children acquire skills that enable children to actively and creatively interact and explore the environment. Games are an important thing for childhood learning. Because child development is increased through play activities, then as an educator must also be able to find the right setrategy and media to use. One of them is like a picture card learning media or flashcard that in the teaching is done by playing. Flashcard is a picture card that contains words. Application of learning media by playing flashcard, besides to recognize numbers faster, children can also recognize letters, words, colors and familiar objects around. Thus, the learning with flashcard media has a positive impact on the development and creativity of early childhood.
\end{abstract}

Keywords: Flashcard; Learning Media; Early Childhood

\section{Introduction}

The main problem of education in Indonesia today is the low quality of education and the unevenness of education in each region. Besides that, it is less efficient and effective and its relevance still needs to be increased. The development of problem is caused by several factors such as the development of science and technology, population growth rate, and lack of facilities and infrastructure that can support the running of an educational process.

Educational technology that is part of education with all aspects of solving the problem of human learning through a complex and interrelated process also participate seeks to increase the quality of education through the ways and methods that are certainly tailored to the needs of growth and development of learners. In educational technology involves a systematic analysis of the overall optimal learning process.

The success of an education is determined by the parties involved in it. Of course, the proper planting of education should start early, which can be done in the family environment, schools and other play groups. In a school environment, teachers have a very important role. Therefore, a teacher should not only have an extensive knowledge, but also be able to choose and apply methods, strategies and learning media that appropriate so that children can more easily understand and absorb as well what they want to delivered.

Early age education is provided to prepare children for further education. As an educator assuming the responsibility of teaching for young children requires commitment, patience and 
understanding. Such responsibilities also require knowledge and skills concerning teaching and learning. Of course the way or method that is used for early childhood differs from other education, because in early childhood education, children will play more. In order to the learning process will run optimal, then an educator must understand about educational technology, in this case is closely related to the methods, strategies and selection of appropriate learning media. One of the media that can be used in early childhood learning is flashcard (picture card).

\section{Method}

This research uses a qualitative approach with a literature study approach. Literature study is research conducted by researchers by collecting a number of books, magazines, liflets regarding issues and research objectives. Research conducted by examining and comparing sources of literature to obtain data that are theoretical. Besides that, by using a literature study the writer can obtain information about the expected research techniques, so that the researcher's work does not constitute duplication.

\section{Result and Discussion}

\subsection{Role of Educational Technology}

Educational technology is basically a field that facilitates an activity in the implementation of human education with the use of various learning resources and the entire process of its implementation. In this case, of course, an educator in carrying out their duties must be able to arouse the enthusiasm and interest of their students so that the learning process can be carried out effectively and efficiently.

Educational technology experts argue that the main role of educational technology is to help increase the overall efficiency of the teaching and learning process [1]. It is intended that with the existence of educational technology it will be able to facilitate students in mastering the material. Thus will be able to increase the quality of learning.

Educational technology includes every possible means (tool) used in learning activities. this is closely related to the tools or media used in education/ teaching. Therefore, the role of educational technology is very large in the World of Education because it is able to support the implementation of a learning activity, so that the goals of the implementation of education can be achieved, because with educational technology the problems of education will be solved so that later the quality of education can be increased.

\subsection{The Nature of Early Childhood Education}

Early Childhood Education is a coaching effort aimed at children from birth to the age of six years which is carried out through the provision of educational stimulation to help physical growth and development so that children have readiness to enter further education [2]. So early childhood education is an effort to optimize children's growth through learning that is more focused on the child through playing activities so that in these activities the child gains skills so as to enable children to actively and creatively interact and explore their environment. Through this interaction and exploration, the child will eventually be able to adjust themself 
with their present environment and the next development environment. Of course this ability is obtained by children through the process of learning, training, integrated guidance and providing a sense of security to children.

The growth and development of early childhood needs to be directed at laying the right foundations for growth and human development as a whole, namely growth and physical development, thinking power, social, emotional, language and balanced communication as the basis of the formation of a whole person. So in the context of early childhood education the true purpose of education is to maximize children's growth and development comprehensively.

According to Mansur that children have the opportunity to develop a series of physical activities, especially at the age of three, the child is able to perform various movements that have been steady, such as running and throwing [2]. Educators (parents and teachers) need to provide opportunities for various activities that are safe for children, but do not expect too much mastery of movements beyond the child's ability. While children aged four and five, even though they are able to sit quietly in a certain time, for example listening story, they still need movement training so that children do not sit too much which will hamper their creativity. Thus as an early childhood educator must know the characteristics of early childhood.

At an early age, children will learn many things through games. Children play at home, at school and all places in their environment. They are play with people, things and ideas. When children sleep, eat or seek emotional support from others, they play and can survive in these conditions for hours. The game belongs to the child from the time they were born until the elementary school year.

If examined carefully program learning activities while playing on early childhood education has a number of functions whichfunction are meant essential part of child development. How important the function of early childhood education because of early age is a fundamental phase for the development and learning of children. Learning and development are continuous processes.

According to Ginsburg, all areas of development were enhanced through children's play activities. Games are a fundamental way in which children get and process information, learn new skills, and practice existing skills [3]. In the context of their play, children become understood, create and manipulate symbols when they take roles and transform objects into other things. Children also explore social relationships and experiment with a variety of social roles, uncovering opposing angles, compromising and negotiating differences. The game allows children to expand their physical pamphlet, language skills and literacy and creative imagination. Evidence that games provide relief from tension, emotional expression and exploration of situations that produce anxiety are also well documented. Thus the game is important for childhood learning.

Knowing children's development and learning is important to be an effective teacher. And to be an effective teacher is important to help children develop and learn. For early childhood educators must have 3 basic knowledge. First, early childhood educators must know what kind of early childhood they are, they must understand children's development and use this understanding to create an early age environment where all children can grow well [4]. Second, the teacher must know about the teaching process and teaching techniques that support learning. Third, they must demonstrate into the knowledge of the academic discipline and related content, most importantly the well-prepared teachers combine all three areas of skills and knowledge in their teaching.

In so many existing learning strategies, in school environments teachers who serve as early childhood educators should really consider the appropriate set of strategies and media used to 
facilitate teaching on the development of their students, as child development is enhanced through play activities, then as a person educators must also be able to find the right strategies and media to use. One of them is like a picture card learning media or flashcard in the teaching is done by playing.

\subsection{How to Implement Flashcard as a Learning Media for Early Childhood}

Early childhood education can be done on the formal education path that is at school, nonformal such as place or groups play and informal education in the family. Early age education can be done as a preparation for children to get further education.

Some media are used to help early childhood learning to provide stimulation of spirit or motivation to children so they can learn easily and fun. Thus they do not feel bored or bored in following the learning process, so that what is delivered can be absorbed by the child well and eventually expected to happen behavioral changes in the form of skills in terms of knowledge, attitude, and skill.

Early childhood education in its principle is to play while learning. Playing while learning is a play activity in which there are elements of learning. This is in line with Broadhead's thought that the need for fun, play is important for intellectual growth and human emotional well-being. while having fun, the human mind uses the ability that develops in childhood to imagine, dream, work, consider, and discover new ways to solve problems [4].

The application of media in early childhood learning is one of them is with a picture card media or called a Flashcard. This can be done while playing, of course the child will feel happy and motivated in participating in learning. Thus, what you want to convey will be easier to understand and absorb well.

Flashcard is a picture card that contains words. Flashcards can be made varied, such as the shape, color and image according to the usage dimensions as an educational game tool (Susanto, 2017: 134). Surely this media uses the ingredients that do not interfere with the child's health, even harmless. According to Ratnawati flashcard or picture card can stimulate the children to know the numbers faster, make the child more powerful to master the numbers, and stimulate the intelligence and memory of children [5].

Application of learning media by playing flashcard, besides to recognize numbers faster, children can also recognize letters, words, colors and familiar objects around. Children will be able to explore using these cards so that they will stimulate various aspects of the child. Thus the flashcard is very good and safe to use for early childhood learning, besides it can develop children's creativity.

A simple example in the application of learning using a flashcard can be done in a way that the teacher took one flashcard and asked the child about the image in the flashcard and how many. This is done repeatedly until the number of cards runs out and the children feel they are quite familiar. After that, the flashcards are placed over the table randomly, and the teacher directs them to look for one of the images in the flashcard, then they will be vying for it vigorously. After the child finds the designated card, the child immediately mentions the type of picture and the number. This is in addition to honing his cognitive abilities, also exercising his physical dexterity. Besides that, the spiritual element can be achieved, for example having the spirit of life for early childhood. In this case, of course the teacher must prepare the media or tools needed before learning begins, so that the learning can run smoothly. With one of these examples, learning with flashcard media has a positive impact on the development and creativity of early childhood. 


\section{Conclusion}

Educational technology is basically a field that facilitates an activity in the implementation of human education with the use of various learning resources and the entire process of its implementation. The role of educational technology is to support the implementation of a learning activity, so that the purpose of the implementation of education can be achieved, because with educational technology, the problems of education will be solved so that the quality of education can be increased. Educational technology includes every possible means or media used in learning activities, for that the selection of media must be tailored to the needs, growth and development of students. Early childhood education is an effort to optimize the growth of children through learning that is more focused on children through play activities so that in these activities children acquire skills that enable children to actively and creatively interact and explore the environment. Early childhood education is a fundamental phase for children's development and learning. Learning and development are continuous processes. Teachers who serve as an early childhood educator should really consider the appropriate strategy and media used to facilitate teaching on the development of their students. In early childhood education, one of the media that can be used is Flashcard or picture card. The use of flashcard learning media is done while playing, of course the child will feel happy and motivated in following the learning and stimulate the children to get to know the numbers faster, make the child more powerful control of numbers, and stimulate the intelligence and memory of children.

\section{References}

[1] N. Uno, H. B. dan Lamatenggo, Landasan Pendidikan. Jakarta: PT. Bumi Aksara, 2016.

[2] R. El Fiah, Bimbingan dan Konseling Anak Usia Dini. Jakarta: PT Rajagrafindo Persada, 2017.

[3] A. P. Kostelnik, M. J., Soderman, A. K., \& Whiren, Kurikulum Pendidikan Anak Usia Dini Berbasis Perkembangan Anak (Developmentally Appropriate Practices). Jakarta: Kencana, 2017.

[4] P. Broadhead, Bermain dan Belajar pada Usia Dini (Dari Penelitian ke Praktek). Jakarta: Indeks, 2017.

[5] A. Susanto, Pendidikan Anak Usia Dini (Konsep dan Teori). Jakarta: PT. Bumi Aksara, 2017. 